\title{
Models of Clientelism and Policy Change: The Case of Conditional Cash Transfer Programmes in Mexico and Brazil
}

\author{
AARON ANSELL AND KEN MITCHELL \\ Monmouth University, USA
}

\begin{abstract}
Clientelist systems vary, and this variation influences the adoption and evolution of conditional cash transfer (CCT) programmes. We find that vertically integrated, corporatist clientelism in Mexico and more locally oriented, bossist clientelism in Brazil differentially shape the choices of governments to turn piecemeal, discretionary CCTs into more expansive and secure benefits.
\end{abstract}

Keywords: clientelism, conditional cash cransfers, social development, Mexico, Brazil.

In the aftermath of the collapse of Import Substitution Industrialisation (ISI), Latin American leaders face similar public sector constraints and continue to adopt similar social policies as part of an ongoing neoliberal restructuring of the state. The use of conditional cash transfer (CCT) programmes and civic committees to channel resources to the local poor are now a staple of policy-making. Yet some lean, ephemeral CCTs are evolving toward more robust and stable measures while others are not. Why?

Social policies under ISI often entailed broad state intervention in markets that permitted universal, non-discriminatory access to both rich and poor, for example, price controls and import-tariffs. But in Latin America, as in most places, social policy is never simply about 'who' accesses benefits, but about 'how' people access them, to whom people feel indebted for them and what they give in return for them. During the ISI era, social policies constituted the social bargain that governments forged with strategic groups such as public and private labour unions, regional bosses, the poor and burgeoning urban middle classes. In other words, social policy walked hand in hand with a mode of clientelism, and state leaders strategised their policy choices with an eye to existing patron-client arrangements. They no doubt continue to do so in the neoliberal era, but how?

By 'political clientelism', we mean 'the distribution (or promise of distribution) of resources by political office holders or candidates in exchange for political support, primarily-although not exclusively - in the form of the vote' (Auyero, 1999: 297). According to social science literature, clients, unlike citizens, naturalise their subordination to their leaders, and thus bargain for resources rather than demanding them as rights (Fox, 1994; Taylor, 2004; Gay, 2006). Yet Hilgers (2008) questions whether the client's

(c) 2011 The Authors. Bulletin of Latin American Research (c) 2011 Society for Latin American Studies. 298

Published by Blackwell Publishing, 9600 Garsington Road, Oxford OX4 2DQ, UK and 350 Main Street,

Malden, MA 02148, USA. 
experience of subordination is universal. Her study shows that clients who participate in the same bargaining process (public housing in Mexico City) can come away feeling both exploited and empowered. At a broader level, Kitschelt and Wilkinson (2007) differentiate national clientelist systems, categorising cases as more or less clientelistic according to a set of criteria, including the relative size of client groups and the extent to which the patrons' gifts to clients are contingent upon the clients' votes. We agree that a systemic level of analysis of clientelism offers the tools to explain the differences in policy introduced above; but systemic variation is not just a matter of 'more' or 'less' clientelism; there are various types of clientelism that are equally clientelistic.

All patron-client exchanges are subsumed within social pyramids comprised of dyadic reciprocities (Landé, 1977). The local patron is the client of a bigger fish, and his client may also view that bigger fish as a potential patron. But which is the more important patron for common people? Which patron informs the client's thoughts? This question must be answered with regard to ISI clientelism in order to understand governments' strategies surrounding the transition to neoliberal social policies. This is the case because changing circuits of resource distribution could discredit patrons whose reciprocal exchanges with citizens legitimated the political system.

This article explores the possibility that variation in systems of ISI-era clientelism has an impact on the way governments undergo a transition to neoliberal social policies. In particular, we argue that two types of clientelism (corporatism and bossism) shape executive branch strategies regarding the timing and expansion of CCTs. We find evidence of this in the cases of Mexico and Brazil. Our first case study focuses on the Mexican transition from the ISI-era food policy, coordinated through the National Food Agency (Conasupo), to CCTs as part of the Progresa programme; the second analyses CCT emergence in Brazil, including the Food Card and Family Stipend programmes. We end by speculating about how our two types of clientelism might influence the choice of governments to turn discretionary social handouts into more stable and far-reaching policies. This article incorporates fieldwork and archival work in Mexico City and northeast Brazil, and interviews (between 1996 and 2006) with local politicians, public sector administrators, civil society actors (unions and private firms) and individual beneficiaries, as well as neoliberal reform architects in Brazil and Mexico.

While Brazil has never had a large-scale ISI-era food distribution policy like Mexico's we have selected these two countries to compare for four reasons: (a) Brazil (at least in the northeast) and Mexico (in the context of Conasupo) epitomise our two idealtypes of clientelism; (b) Mexico's neoliberal social policy package would later guide Brazilian policy-makers towards CCTs, local development projects and municipal civic committees; (c) reforming executives in both countries used neoliberal policy innovations as tools to undermine the erstwhile modes of clientelism of their respective countries; and (d), despite the above similarities, today these CCT programmes are expanding rapidly in Brazil but not in Mexico. Our two categories of clientelism help us to account for different CCT performance.

\section{Two Ideal Types of Clientelism: Corporatism and Bossism}

A foundational scholarship dealing with the transformation of clientelist systems posits that modernisation links local patron-figures to emerging state institutions (Lemarchand and Legg, 1972; Eisenstadt, 1973). Thus, clientelism during the ISI era 'adapted very well to inclusionary party-politics through its vast party machine anchored in the poor 
barrios and trade unions' (Taylor, 2004: 220). This is consistent with understandings of twentieth-century populism that claim that charismatic figures (Peron, Vargas, etc.) used new media technologies to project their personal selves into the minds of urban masses more accustomed to face-to-face patronage. This remote personalism arguably facilitated a far less personal attachment of poor people to a political party, a union conglomerate and, ultimately, to the state. This is the corporatist type of clientelism.

Corporatist vertical alliances do not preclude more personal hierarchies at the barrio or local union level (Auyero, 1999). On the contrary, they entail the seamless nesting of local patrons within the larger corporate state. However, these local figures are not the primary patrons structuring common people's relationship to the political order; they are the gatekeepers whom larger institutions authorise to make small-scale decisions on behalf of those institutions. In its ideal-typical form, commoners view the state as their main benefactor, and hold it accountable for resource distribution.

At the opposite end of the continuum are clientelist polities in which common people care little about the world outside their face-to-face community, and prioritise their political exchange efforts on the local mayors, aldermen or landowners. We refer to this as bossism. Even if common people know that the goods that the local boss gives them originate from outside (state or federal) institutions, it is the local boss who, in Lucy Taylor's (2004) words, 'informs the client's thoughts' (p. 215). The client believes that the boss both actively procured these resources from higher-ups, and that the boss selected him or her (as opposed to others) to personally receive them. The client believes that without the boss's intervention on his or her behalf, he or she would have nothing. Thus, when resource streams dry up, the local boss, not the state, is held responsible.

Mechanisms of exchange for bossism and corporatism differ. Bossism tends to emerge under fragmented multi-party competition at both the local and national levels; corporatism, at its most extreme, develops under a hegemonic party, or, at least, limited electoral competition. Partisan loyalty and dissent within bossism tend to be intimate. People are primarily loyal to individuals, and only secondarily to party organisation. The language of loyalty in a bossist system is often one of friendship and kinship, and kinship ties such as godparentage, in-law relations, and actual consanguinity bind patrons and clients to one another. In addition to the organisational resources from above that local bosses channel to their clients, bosses also earn people's loyalties through car-rides, favourable intervention with police and judges, invitations to family meals and purchase of medicines. The client's currency consists of the municipal vote, participation in local rituals of largesse, favours given to the boss's other clients and the celebration of the patron's person upon his arrival at social events. On the other hand, common people in corporatist systems tend to be loyal primarily to nationally integrated institutions (parties and bureaucracies), and only secondarily to local individuals who lead national institutions. The corporate patron (a vertically integrated party or bureaucratic organisation) earns loyalty through the dispensation of organisational resources (union benefits, cheap food programmes, infrastructure) to people who express loyalty to the larger institution. Clients express loyalty to national institutions by purchase of their branded commodities, by attendance at their strikes and rallies, and by turning a blind eye to their corruption. These actions occur locally and may include deference to local figures, but symbolically construct their patron as a national entity. Thus, kinship relations are not the primary idiom binding clients and patrons in corporatist systems, even though local kinship relations could draw people into larger national institutions.

The reason that electoral competition shapes the formation of these two types of clientelism is that more stable national authority discourages local leaders from 
challenging the ruling party because they have few other options for support at the national level. Thus, in a hegemonic-party state local patrons want to depict themselves as the ideal representatives of the party or bureaucracy that monopolises resources. In so doing, the local patron reinforces commoners' identifications with these larger institutions. Some multi-party states in which social services are continually identified with a particular party (e.g. Peronism in Argentina) offer a slightly milder form of corporatist clientelism. However, when national parties begin to compete for branding rights, local patrons may assume some independence from the national institutions.

A bossist system is likely to emerge when different parties circulate in and out of power at the national level, because local patrons can play various national allies off against one another. Alteration of national parties and bureaucratic leaders make local patrons more constant figures than are national institutions. Even when local bosses compete to represent whichever party holds power, they have little incentive to remain loyal to that party when it is defeated (Leal, [1949] 1977). Thus, the boss's relation to the central authority is that of a wily trickster, always flexible, and always ready to switch his or her party affiliation. As such, the commoner attaches himself or herself to the local boss, trusting that this person will navigate the turbulent waters of national party politics.

These two categories are polar 'ideal types' intended to accentuate graded differences in state-society reciprocal exchanges. As 'ideal types', these categories are not meant to grasp the subtleties of each country in which there are spatial and temporal variations with respect to the many gradations possible along this continuum. For example, the Mexican case study below explores resource circuits that link the state to urban households (largely in and around Mexico City). This does not discount the significance of rural bosses or caciques in Mexico, either during ISI or today (Knight and Pansters, 2005). Similarly, our Brazilian case study focuses on the dynamics of bossist clientelism in the northeastern region, where mayors are the key patrons (Ames, 2002; Samuels, 2002; Gay, 2006). Other clientelist systems and circumstances prevail across Brazil. Yet put into the context of the transition from ISI to neoliberal social policies, the above difference between these two forms of clientelism help to illuminate the different challenges and advantages for executive policy reformers.

\section{Corporatist Clientelism and Policy Change in Mexico}

Affordable food constitutes a clientelistic resource circuit linking the Mexican state to strategic sectors of society. Cheap food during the ISI era, a time of hegemonic party rule under the Institutional Revolution Party (PRI), consisted of expensive universal price controls and less expensive direct food handouts run by the National Food Company which existed from 1961-1997. By 1989, neoliberal policy-making lifted price controls and narrowed clientelist exchange to Conasupo handouts and new presidential-identified CCT schemes. In 1997, a specific CCT, Progresa, officially replaced Conasupo; yet, less policy innovation transpired here, as important Conasupo handouts shifted to the Social Development Ministry (Sedesol).

The case study below uses Conasupo termination as a way to illuminate how corporatist clientelism influenced CCT adoption. The path to this pivotal juncture, the consequences for state-society relations and for corporatist clientelism, and the circumstances that surround post-Conasupo policies, are not well understood. Why did a PRI (not an opposition) president terminate a corporatist institution that had benefited 
the party politically? Indeed, the president and the PRI suffered electorally-axing Conasupo supported the left-centre campaign against the PRI, leading to the opposition's watershed mayoral victory in Mexico City in 1997.

Why have opposition presidents since 2000 maintained PRI policies from the 1990s? Conasupo became an arena for intra-PRI power contestation. Axing Conasupo shifted power away from a corporatist bureaucracy, inseparably intertwined with the durable PRI, and towards the constitutionally term-limited president. In part, this outcome altered popular perceptions about who was the patron when it came to consumer subsidies. Scrapping Conasupo and placing consumer subsidies under tight executive (not corporatist partisan) control after 1997 recalibrated state resource distribution in a way that reflected Mexico's political shift from a hegemonic party system to a party system in which three parties compete nationally. It is the legacy of corporatist clientelism that helps explain why opposition presidents since 2000 have maintained old PRI policies (and why future presidents are apt do the same).

\section{Phase 1: The Rise of Corporatist Policy}

The Wheat Market Regulation Committee (1937-1938) formalised previously ad hoc state food programmes designed to combat price speculation and political instability in Mexico City. Explosive population growth in Mexico City led the state to centralise various food programmes under Conasupo in 1961. Legendary priista Carlos Hank González ran Conasupo from 1965 to 1968 and promised Conasupo supermarkets in every neighbourhood in and around Mexico City. Surveys of these burgeoning communities during this period suggest that he delivered as promised, as 70 per cent of households received Conasupo food (Cornelius, 1975).

Consumer food subsidies created three advantages for the PRI. First, consumer price controls for food boosted the PRI's 'revolutionary credentials' and defused leftist partisan challenges. Second, direct Conasupo food handouts lubricated PRI corporatist relations between its National Peasant Confederation (CNC), its National Confederation of Popular Organisations (CNOP), and its Confederation of Mexican Workers (CTM). Conasupo's nation-wide food outlets operated via three main programmes: (a) the Rural Supply Programme, co-administered with the CNC; (b) the Popular Urban Programme, co-administered with the CNOP; and (c) the Union Store Programme, coadministered with the CTM (Diconsa, 1985; Conasupo, 1988). Conasupo's daily milk programme (Liconsa) cultivated strong ties to the CNOP's popular urban-based groups. Conasupo's annual open forum with 'housewives' brought together CNOP leaders of local barrio groups to discuss local Conasupo operations. State patronage (and public sector jobs) formed the incentive structure of the hegemonic political system, and, with food subsidies, political negotiations (or concertación) between Conasupo and the PRI's corporatist branches determined the location and supply of food stores. Thousands of concertación agreements took place at the start of each new six-year presidential term in a ritual whereby PRI corporate leaders pledged support to a new PRI president in return for continued and additional Conasupo resources.

Third, food policy permitted clientelistic arrangements outside of formal corporatist branches. On the one hand, Conasupo carrots helped to co-opt independent popular neighbourhood organisations around Mexico City, as occurred in the wake of the disputed 1988 presidential contest. On the other hand, Conasupo's vast distribution infrastructure required thousands of concertación pacts with private food suppliers and other intermediary service providers. 


\section{Phase 2: Crisis of Corporatist Policy during 1980s}

Oil wealth inflated consumer food subsidies in the 1970s and collapsing oil prices did the opposite in the 1980s. Price controls stopped as part of structural adjustment, except for tortillas, rice, beans and milk - these would be discontinued later. However, Conasupo handouts to corporatist branches continued to the point where, during the 1980s Debt Crisis, only PEMEX surpassed Conasupo's budget (Gobierno Mexicano, 1988: statistical annex). Reflecting the traditional corporatist focus on Mexico City, as late as 1988, it accounted for 70 per cent of state food subsidies (Conasupo, 1995).

Initial austerity during the 1980 s elicited the first official programmes to target food subsides to 'only the neediest households' (Salinas, 1988). Raúl Salinas, brother of Mexican president Carlos Salinas (1988-1994), oversaw this policy shift in his capacity as director of Diconsa (1982-1988). Initial targeting furnished additional resources to corporatist branches, part of anti-inflationary pacts. For example, the three primary beneficiaries of a pilot programme that targeted credit at Diconsa stores were the National Sugar Workers' Union, the State Rural Bank Workers Union and the Coffee Workers Union of Nayarit (Salinas, 1988). By the time of the Salinas administration, then, universal access to subsidised food had largely stopped, while corporatist and targeted handouts continued, although not necessarily under the same operational arrangements that prevailed during the ISI-era.

\section{Phase 3: Corporatist Clientelism and Policy Change in the 1990s}

Under the PRI administrations of Salinas (1988-1994) and Zedillo (1994-2000), Conasupo concurrently expanded (handouts grew) and shrunk (processing plants and large urban stores were privatised) before being abruptly terminated in 1997. Traditional PRI supporters broke ranks and voted for the left-centre opposition in 1988, prompting Salinas to reorganise social sector policy via his vast National Solidarity Programme (Solidarity). Solidarity created local solidarity committees (150,000 of them by 1994). These grassroots groups, comprised of locally elected residents from poor communities, directly communicated local demands for public services and resources (including for Conasupo infrastructure) to the executive branch. In terms of food subsidies, solidarity committees bypassed traditional PRI corporatism, marking a first phase toward the conversion of subsidised food to cash transfers as the main currency of state clientelism. These committees centralised cash transfers under tight executive control, and linked food handouts (a small portion of the budget) more to the president than to Conasupo.

The Solidarity literature often misrepresents Conasupo operations under Salinas. Salinas in effect constructed parallel exchange structures for Conasupo resources. For example, under Salinas and Zedillo (prior to 1997), the executive branch signed Conasupo concertación agreements for Liconsa and Diconsa infrastructure with both PRI corporatist branches and the non-corporatist solidarity committees. The Solidarity literature focuses on the latter and overlooks the former. Overall, Conasupo food handouts under Salinas amounted to a 'positive sum' rather than a 'zero-sum' policy innovation.

Signing corporatist concertación pacts did not preclude efforts to reform Conasupo. Salinas's Conasupo Modernisation Plan of 1989 sought to balance old and new exchange relationships (Conasupo, 1994). Overall, it aimed to deliver food to half of the Mexican population. Targeted distribution grew during the Salinas term; in fact, it almost doubled in the months prior to the mid-term election in 1991. Funds for this expansion came in large part from privatising Conasupo's powdered milk reconstitution 
facilities, flour mills and cooking oil plants (to private sector PRI supporters) - a political 'win-win' situation (Conasupo, 1992).

After the 1991 mid-term election restored PRI dominance (left-centre opposition percentage of the national vote fell from 29.6 in 1988 to 8.9 in 1991), Salinas engineered another assault on corporatist food policy by ordering the first independent verification of Conasupo operations (Conasupo, 1993). Verification followed earlier moves by Salinas in the form of solidarity committees. The verification pilot took place in the PRI stronghold of Colima - Conasupo acknowledged that it would be too difficult to verify in Mexico City (Conasupo, 1993). Findings pointed to a high leakage rate and a significant middle-income bias. Subsequently, Salinas contracted private-sector firms (unheard of previously) to clean up and monitor Conasupo operations outside Mexico City. By 1994, leakage rates outside Mexico City dropped, and the rural poor received a larger percentage of Conasupo handouts, in part due to Salinas's closing of all large urban Conasupo supermarkets, long a perk for middle-income Mexico City residents (Conasupo, 1994). Mexico City's share of Conasupo tortilla subsidies dropped from 43 per cent in 1990 to 10 per cent in 1994 (Conasupo, 1995).

The initial PRI candidate for president in 1994 was Luis Donaldo Colosio, the solidarity director under Salinas. Colosio was assassinated on the campaign trail and replaced by Ernesto Zedillo (Colosio's campaign manager), who campaigned on and indeed continued President Salinas's parallel exchange arrangements involving Conasupo and solidarity committees, as well as the associated verification policies. However, the Solidarity brand that loomed large in the autumn of 1994 turned toxic after the December 1994 peso crisis and the ensuing corruption scandals of President Salinas and his brother. In 1997, the Progresa programme officially replaced Conasupo and Solidarity (disbanding the solidarity committees), a knee-jerk attempt to turn the page on the Salinas years prior to the 1997 mid-term election. Progresa, soon inseparable from President Zedillo, quickly expanded a Conasupo CCT pilot scheme (PASE) from the state of Campeche that provided small-cash payments to poor mothers who kept their children in school and kept regular medical visits.

Liconsa and Diconsa continued via concertación agreements with PRI corporatist branches, albeit under the auspices of Sedesol; yet Progresa began a new phase in executive-community exchange arrangements - a further progression from corporatist exchanges to executive-local committee exchanges to (under Progresa) executive-family exchanges. Under Progresa, Sedesol interviewed (i.e. carried out a socio-economic survey of) families directly. Hegemonic party rule and PRI corporatist food policy did collapse, although the corporatist legacy continues to shape consumer subsidy policies. The 1997 mid-term election ended PRI control over Mexico City. The mayor from the left-centre Party of the Democratic Revolution (PRD) quickly started a PRD milk programme (with its colours on milk cartons) to compete with the traditional PRI Liconsa programme.

In 2000, PRI corporatism collapsed in full as the right-centre National Action Party's (PAN) Vicente Fox captured the presidency. A firm break in terms of political exchange relationships oversimplifies recent circumstances. Liconsa and Diconsa food stores continue to expand, although traditional arrangements with the PRI's CTM, CNC and CNOP stopped after 2000. Interestingly, President Fox's community-based Diconsa rural committees and councils harked back to the days of the PRI's solidarity committees. He turned Diconsa into a public-private partnership; yet, the announcement in January 2005 that the Diconsa food stores (over 22,000) would no longer purchase imported food, rekindles a familiar populist (non-neoliberal) logic (El Economista, 12 January 
2005). In an ironic twist, Heladio Ramírez, leader of the PRI's CNC, called for this move back in June 2003! Fox also expanded Progresa and renamed it Opportunities. Opportunities and Fox (not the PAN) soon became inseparable, much as past policy was inseparable from PRI presidents. Again, the challenge in Mexico's increasingly electorally competitive policy context appears to relate back to the corporatist legacy of tying resource circuits to the president and not his (or another) party, his successor, or a neutral public sector.

For the purpose of comparison, we draw attention to two aspects of the Mexican case relayed above. First, no time lag occurred between the Mexican government's termination of ISI policy and the initiation of CCTs. The one was phased out as the other was phased in. Second, the government used civic committees for policy selection. The goal was to shift the beneficiaries' perceptions from universal food benefits ('price controls') to cash transfers, and to reorient local people's sense of their patron away from the national corporatist institution (Conasupo) and towards the figure of the executive. The Brazilian case discussed below shows some contrasts with these two points that we believe are related to differences in the type of clientelism predominant there.

\section{Bossist Clientelsm and Policy Change in Brazil}

Brazilian ISI social policy arose sporadically during the New State (1930-1945), populist era (1945-1964) and military dictatorship (1964-1985) in order to facilitate urbanisation, and to reduce the political challenge that came from the concentration of poor people in the cities. Popular restaurants, food distribution programs and school lunches reduced the cost of labour to employers and inculcated worker loyalties to the state and to a few large labour parties (L'Abbate, 1989). In the countryside, ISI policies including government intervention in food prices, agricultural subsidies, rural credit, tariffs on food imports and development projects from para-state enterprises supported rural workers. But Brazil never developed a single, national food distribution programme that endured for decades like Mexico's Conasupo. Hyperinflation during the 1980s eviscerated many of these programmes, as did the neoliberal reforms of the 1990s. The decade saw a contraction of rural credit, the termination of the para-statal Superintendency for the Development of the Northeast, rising interest rates, the freezing of rural pensions, decreased spending on basic healthcare, sanitation and education, the termination of government price-setting and the opening of trade barriers to foreign agricultural companies (Helfand and Rezende, 2001; Novelli and Galvão, 2004). While these rollbacks had occurred throughout the decade, it was only in 1999 that the federal government, under Cardoso, initiated CCTs to ameliorate the damage these measures had done to the poor.

Having stabilised Brazil's spiralling currency crisis in 1992, President Cardoso, a neoliberal technocrat, began experimenting with targeted cash grants in his second term (1998-2002). School Grant, Income Grant and Gas Aid - all launched between 1999 and 2001 - gave cash to a limited number of poor families under certain conditions. Under School Grant, for instance, families received a certain amount of money per child, provided that the child attended school (similar to Mexico's Progresa programme).

When Cardoso began implementing cash transfer programmes, he knew that local mayors would mediate the distribution of these resources. Rather than confront them head-on, his administration shaped the way that they would effect this mediation. Cardoso mandated the formation of municipal civic councils for each programme, 
whose members were handpicked by the mayor. These councils enrolled poor people in a national list called the Unified Registry, which housed demographic data about these families that the federal government used to determine eligibility for the grants (Hall, 2006).

Cardoso's grants did little to improve the success of his Brazilian Social Democratic Party (PSDB) in the 2000 municipal elections. Maybe it was too soon for the young programmes to make their impact; maybe mayors from opposing parties co-opted them effectively. Either way, the PSDB made only very small electoral gains (Fleischer, 2002: 90). And by this time, Brazilians were feeling the pains that come with privatisation and new currency problems (Kinzo, 2003: 66; Roett, 2003: 202).

\section{President Lula and the Zero Hunger Programme (2003-2004)}

The Workers' Party (PT) presidential campaign against the incumbent PSDB mobilised a visceral rhetoric of hunger that pitted Lula's humble persona against his technocratic opponents. In January 2003, President Lula launched the heavily publicised Zero Hunger Programme, which he claimed would provide all Brazilians with three meals a day.

The Zero Hunger Programme was designed during the campaign, and emerged from three sites: a left-wing NGO called the Citizenship Institute, the UN Food and Agriculture Organisation and a forum of social movements allied with the PT (Leher, 2003: 84). The Lula government placed Zero Hunger under a newly created Ministério Extraordinário de Segurança Alimentar (MESA; Special Ministry of Food Security), and initiated Zero Hunger as a complex combination of food-basket and milk distributions, crop purchases, water-infrastructure projects and cash stipends. The cash grant, Food Card, received by far the most government investment, and the government spread it throughout the northeast faster than any other sub-programme. By the end of 2003, Food Card benefited nearly 2 million families (Balsadi, del Grossi and Takagi, 2004: 89-92).

Food Card was an eighteen-month stipend of 50 Brazilian reais per month (about US\$15-20) that went to the female heads of indigent households in the form of a magnetic card. This represented a 21.1 per cent increase from Cardoso's cash-grant expenditures (MDSCF, 2004; Hall, 2006), and was enough for a family of four to buy a two-week supply of food.

\section{Zero Hunger's Initial Implementation in Passerinho, Piaui}

Zero Hunger's Food Card arrived in its two pilot towns in January 2003. Both towns were remote, small and rural places in the backlands of Piaui, the only northeastern state with a PT governor. In January, a mixed federal-state team drove into the countryside to advise people in the two towns - and later others - that they were to receive Zero Hunger benefits. In one town, which we will call Passerinho, the erstwhile mayor from the catch-all, centrist Brazilian Democratic Movement Party (PMDB) considered the local PT to be his enemy, but, like most mayors, he maintained a flexible posture with regard to state and national political leaders.

This opposition camp consisted of an alliance between the PT and a larger group affiliated with a wealthy rancher-businessman who belonged to the right-wing Liberal Front Party (PFL). While at the national level, the PT and the PFL were ideologically opposed, in Passerinho, they were drawn together by the fact that their respective 


\section{Models of Clientelism and Policy Change}

leaders were siblings. The team sent field reports to the MESA indicating that the local opposition claimed the mayor had played favourites with extant Cardoso CCTs: 'The Registry shows only the families that are benefited by the grant'; 'Those who need it are not on it; some have it without needing it'; 'Our local commissions do not operate in practice'; 'the power is centralised with the mayor' (Coordinadoria do Fome Zero-Piaui, 2003). These reports account for Anthony Hall's (2006) finding that only 70 per cent of Brazil's poor were listed in the Unified Registry at that time (p. 696).

The MESA officials knew that channelling Zero Hunger monies through municipal councils hand-picked by the mayors would compromise their targeting of the poor. The Ministry thus mandated the formation of municipal 'management committees' to select Zero Hunger's beneficiaries in all 2285 municipalities in which Food Card was implemented (Balsadi, del Grossi and Takagi, 2004: 85-88). Unlike Cardoso's counsels, the Zero Hunger committees were elected in a general assembly. MESA provided the general eligibility criteria for Food Card that the committees could further specify.

In Passerinho, the PMDB mayor was furious at the Lula government. Creating elected committees to 'run his house for him' was a slap in the face. In his view, the Lula government had denied him his right to represent himself as the central benefactor of such resources. Reports from state counsellors throughout the northeast given at the Second National Food Security Meeting in Teresina in February of 2005 indicated that many mayors had reacted to Food Card with similar indignation.

Mayoral outrage fueled partisan rivalries on Zero Hunger committees. Our interviews with state counsellors and committee members in Passerinho suggested that the limited spaces available for beneficiaries encouraged accusations of partisan distribution, especially as the municipal campaign season 'heated up' in 2004. Even though Food Card had expanded CCTs, they were still a scarce resource. In Passerinho, many people understood that Food Card's distribution was determined by the committee, not the mayor. The mayor's allies tended to blame the opposition-dominated committee for 'dirty politics' if they did not receive Food Card, while supporters of the local opposition generally blamed the mayor's allies on the committee if they did not receive it.

Thus, if the Passerinho case is generalisable to other municipalities, it would suggest that Zero Hunger committees were partially successful in displacing the mayor from the role of local resource provider. But the Lula government paid a price. While mayors had typically provided meeting spaces and resources for the councils that had overseen the Cardoso grants, Zero Hunger committees worked with no guaranteed meeting space, no funds for supplies and no access to the municipal computer. Throughout the northeast, mayors were starving the committees of these resources, crippling the programme and reinforcing discourse about the Lula government's 'incompetence'. Alienating mayors from the PMDB came with an added risk. The PMDB held the plurality of mayorships in the northeast and nationally (Nicolau, 2007), and many seats in all legislative bodies (Samuels, 2008). Lula needed legislative alliance in 2004, and if local PT candidates could run as deputy-mayors on PMDB-dominated tickets, the PT could get a foothold in municipal public offices throughout Brazil. It was rumoured among PT activists and Food Security counsellors in Teresina that PMDB mayors throughout the northeast were refusing such local alliances with the PT. The national PMDB was too weak to impose local alliances on its municipal officials, but if the PT axed the management committees, PMDB leaders might prevail upon the mayors. 


\section{The Municipal Elections of 2004 and the Transition to Family Stipend}

In late 2003, the federal government shifted its programmatic emphasis from Zero Hunger to a new programme, because the public perceived Zero Hunger as a failure (Hall, 2006: 696). It replaced the MESA with a new Ministry that combined Food Card with the pre-existing Cardoso grants, creating a new flagship programme, Family Stipend. The Lula government flooded the poor with Family Stipend; even families that earned more than 90 reais per capita qualified for some components of this CCT. The Brazilian congress passed legislation that took the programme one step closer to a federal entitlement (Law 10.836, January 2004), but stopped short of a constitutional guarantee of the Food Stipend to all poor people. The federal government retained the right to 'balance the number of available grants with existing budgetary endowments' (see the Special Clause under Article 5 of Law 10.836). Still, the abundance of grant spaces that the government allotted for created a de-facto entitlement, or at least an atmosphere of security, for the poor (see Kerstenetzky, 2008).

By the time Family Stipend got underway in 2004, it was clear that the new minister, Patrus Ananias, would return to the mayors the all-important control over the Unified Registry (Portaria GM/MDS 246, 2005). The elected committees were de-fanged. The new legislation allowed the mayors to control the selection of the beneficiaries. While Ananias arguably increased the potential for mayoral bossism to return to the CCT allocation process, the expansion of Family Stipend was so great that there was no scarcity of CCTs for the poor. The new minister also created formal grievance procedures for people who believe that irregularities have occurred in their municipality.

It is difficult to determine the extent to which returning control over the Unified Registry to the mayors resulted in the latter's meddling with local poverty assessment. Investigations into the Family Stipend's efficiency in targeting indicate that clientelism still has an impact on the programme (Hall, 2006), though less so than it did the Cardoso grants (Soares, Soares, Medeiros and Osório, 2006). Indeed, while Family Stipend returned control of the list to mayors, it may have taken away much of the incentive for mayors to list only their allies. Municipalities are not allotted a finite number of spaces in the programme at this point, so it costs nothing for a mayor to enrol an adversarial family, and begrudging the grant to an enemy appears crueller when most people receive the grant. The mayor's de facto discretion over allocations thus diminished when Lula expanded the coverage of CCTs. Mayors may still intervene to enrol middle-class people in Family Stipend, but this did not alter the public's perception that Lula had given them the Family Stipend. After all, they could plainly see that even people who opposed the mayors received Family Stipend. In the 2006 federal/state elections, Lula was so easily re-elected because he had picked up the support of the poorest sectors of Brazilian society that had traditionally voted more conservatively (Nicolau, 2007).

\section{Discussion}

In both Brazil and Mexico, national executives implemented CCTs in order to secure electoral support of the poor by giving them cash, an innovation intended to undermine the erstwhile clientelist systems of bossism and corporatism, respectively. Our case studies show how the different types of clientelist systems created different opportunity structures leading Mexican and Brazilian presidents to make different choices about the 


\section{Models of Clientelism and Policy Change}

timing of CCT initiation, and the use of local committees to manage the CCTs. Furthermore, we can extrapolate from these findings that presidents in bossist contexts are likely to extend CCTs to increasingly broad swathes of the population, while in corporatist (or post-corporatist) contexts, presidents are more likely to limit the coverage of CCTs.

\section{Timing of CCT Initiation}

In corporatist systems, national executives (and their parties) assume more accountability when policies go right or wrong than do presidents in bossist contexts, because the latter divide credit and blame with local mayors. Thus, corporatist-system executives are more wary of ending ISI distribution programmes than bossist-system executives. If they want to end a popular ISI programme, they have to phase it out slowly and replace it simultaneously with something else. Indeed, Mexico saw a very slow phasing-out of most ISI policy in the area of food programmes (i.e. price controls and later Conasupo), and the simultaneous refashioning of policy via a parallel CCT (Progresa/Opportunities) and a few traditional government handout programmes. The latter, no doubt, were designed to compensate for the squeezing of the former, and thus helped to preserve some legitimacy for the state in the context of popular expectations derived from a corporatist legacy. Indeed, Salinas quickly expanded targeted food handouts after his disputed 1988 election, and significantly scaled them up in the run-up to the PRI's successful mid-term election of 1991. The same thing occurred with ending Conasupo and simultaneously replacing it with Progresa. In Brazil, on the other hand, considerable time elapsed between the cuts to ISI policies (and the dismantling of para-state agencies that aided the poor and middle class) in the early 1990s, and the implementation of neoliberal targeted benefits in 2000 under Cardoso (and later expanded under Lula). The neoliberal executives running Brazil during the 1990s could afford to do this politically because it is our experience that poor people in the rural northeast tend to hold their local patrons partially responsible, thus, allowing Cardoso (re-elected in 1998) to weather the adverse effect at the polls.

\section{Local Committees}

Once ISI programmes have been cut or phased out, the next problem is for the executive to assume maximum credit for distributing targeted cash grants. In both corporatist and bossist contexts, presidents have good reason to employ local committees to manage CCTs. Local committees help to redirect loyalties toward the president and away from either national distributive institutions (corporatism) or mayors (bossism). In Brazil, Lula took the mayors out of the distribution circuit by assigning elected committees the job of selecting Zero Hunger beneficiaries. In a corporatist Mexico, Salinas's use of committees switched the national patron: the executive replaced the traditional corporatist Conasupo despite the fact that many food programmes did not change.

But local committees fare differently in corporatist and bossist contexts. In a corporatist system, local committees are less threatening to the leaders of national goodsdistributing institutions. Those institutions constitute independent resource circuits. Thus, Salinas's committees did little to detract from Conasupo's prestige. Salinas had to co-opt Conasupo at the national level by putting his brother in a leadership position. In Brazil, on the other hand, local committees threatened the erstwhile patrons, because patronage loyalties were municipal. The mayors fought back by starving the committees 
of work resources (and perhaps by appealing to higher-up PMDB officials to pressure Lula into axing the committees). And they won. Thus, while committees are more of a threat to bossist clientelism than to corporatist clientelism, bossism, as a system, is more able to resist presidential centralisation than corporatism.

\section{Extending the Coverage of CCTs}

The above findings allow us to speculate about the fate of CCTs in bossist versus corporatist contexts. Presidents are more likely to extend CCTs to broad swathes of the population in bossist clientelist settings, because there is a greater electoral risk associated with partial coverage. If spaces in a CCT programme are limited, more discretion exists among opposition mayors who can capture credit for the programme by selecting the benefiting families. Thus, in order to ensure that CCTs translate into electoral gains for the president, local discretion has to be attenuated through the extension of coverage to all the poor, and poverty has to be defined loosely enough that most of the population receives the CCT. Under corporatism, presidents do not worry about local mayors stealing credit by using their discretion in allocating more limited CCTs. They worry about co-opting the credit previously afforded to other national institutions. They do not have to spend as much of their budget to achieve electoral rewards.

Data on CCT extension in Mexico and Brazil bear this out. Between 2003 and 2009, the coverage of Brazil's Family Stipend inflated from 1.2 to 12.4 million families (www.mds.gov.br/bolsafamilia [accessed 30 August 2010]). Moreover, families do not have to be in 'extreme poverty' in order to receive Family Stipend; middle-class families can still receive the portions of Family Stipend that subsidise schooling. On the other hand, Mexican CCT expansion via Opportunities has grown much more slowly over the same period - 4.2-5.0 million families between 2002 and 2009 - covering nowhere near the entire 'poor' population (Figures from the Sedesol website, see Sedesol, 2010). Mexico maintains a more restrictive measure of poverty. Mexican budgetary constraints have been tighter than those in Brazil in the 2000s, but the slow expansion may also reflect the fact that there has been less to lose (in electoral terms) by keeping CCTs limited.

\section{Conclusion}

CCT evolution in both Mexico and Brazil featured attempts at executive centralisation, but the shift toward presidential leadership undermined corporatist clientelism more easily than it did bossism. Indeed, Mexico is now in a post-corporatist moment of multi-party presidentialism. But Mexico's current political system remains centralised. We might frame this as a shift from one national patron (Conasupo) to another (the president). This is an easier shift for a president to accomplish than a shift from localist bossism to national presidentialism. While Lula might be slowly centralising popular loyalties in his office, he has had to abandon his direct assault on local bosses. Rather than bypass them with committees, he floods local mayors with goods.

CCT policy has become a pivotal tie binding state and society in the neoliberal era. Latin American executives who shift ISI policies to CCTs face a common challenge: to pursue this policy change without undermining their overall political legitimacy and electability. We have argued that distinguishing between bossist and corporatist models of clientelism helps to explain why Brazilian and Mexican presidents made different choices about CCTs. Conversely, examining CCT programmes in terms of their effects 


\section{Models of Clientelism and Policy Change}

on patron-client reciprocities helps us understand why these programmes more easily shore up presidentialism in Mexico than in Brazil. As observers of future social sector reform try to make sense of new transitions, considering the nature of pre-existing forms of state-society relations is a good place to start.

\section{References}

Ames, B. (2002) The Deadlock of Democracy in Brazil. The University of Michigan Press: Ann Arbor.

Auyero, J. (1999) “"From the Client's Point of View": How Poor People Perceive and Evaluate Political Clientelism'. Theory and Society 28(2): 297-334.

Balsadi, O., del Grossi, M. E. and Takagi, M. (2004) 'O Programa Cartão Alimentação (PCA) em números: balanço de sua implementação e contribuição para as políticas sociais'. Cadernos do Centro de Estudos Avançados Multidisciplinares (CEAM) IV(14): $81-99$.

Conasupo (1988) CNC-Conasupo, 50 anos de lucha por la alimentación. Disconsa: Mexico City.

Conasupo (1992) Informe de autoevaluación correspondiente a 1992. Conasupo: Mexico City.

Conasupo (1993) Informe de autoevaluación correspondiente a 1993. Conasupo: Mexico City.

Conasupo (1994) Informe de autoevaluación correspondiente a 1994. Conasupo: Mexico City.

Conasupo (1995) Conasupo: su función social. Conasupo: Mexico City.

Cornelius, W. (1975) Politics and the Migrant Poor in Mexico City. Stanford University Press: Stanford.

Cria o Programa Bolsa Família e dá outras providências (2004) Presidência da República. Casa Civil. Law 10.836, January 9. [WWW document]. URL http://www.planalto.gov. br/ccivil/_Ato2004-2006/2004/Lei/L10.836.htm Site [accessed 13 November 2010].

Diconsa (1985) Diconsa: 1983: las tiendas serán centros integrales de distributión y servicios conasupo. Diconsa: Mexico City.

Eisenstadt, S. N. (1973) Traditional Patrimonialism and Modern Neopatrimonialism. Sage Publications: Beverly Hills.

El Economista Editorial (2005) Comprará Diconsa a productores mexicanos: Fox, 12 January. [WWW document]. URL http://www.eleconomista.com.mx/index.php [accessed 12 November 2010].

Fleischer, D. (2002) 'The 2000 Brazilian Local Elections'. Opinião Pública 8(1): 80-105.

Fox, J. (1994) 'The Difficult Transition from Clientelism to Citizenship: Lessons from Mexico'. World Politics 46(2): 151-184.

Gay, R. (2006) The Even More Difficult Transition from Clientship to Citizenship: Lessons from Brazil, Out of the Shadows: Political Action and the Informal Economy in Latin America. The Pennsylvania State University Press: University Park, 195-219.

Gobierno Mexicano (1988) Informe de Gobierno, Statistical Annex. Presidencia de la República: Mexico City.

Hall, A. (2006) 'From Fome Zero to Bolsa Família: Social Policies and Poverty Alleviation under Lula'. Journal of Latin American Studies 38(4): 689-709.

Helfand, S. and Rezende, G. (2001) The Impact of Sector-Specific and Economy-Wide Policy Reforms on Agriculture: The Case of Brazil, 1980-1998, Working Paper. University of California: Irvine.

Hilgers, T. (2008) 'Causes and Consequences of Political Clientelism: Mexico's PRD in Comparative Perspective'. Latin American Politics and Society 50(4): 123-154. 
Kerstenetzky, C. L. (2008) Development and Redistribution: The Case of the Bolsa Familia Program in Brazil. Textos Para Discussão UFF/Economia, 1-35.

Kinzo, M. A. (2003) 'Parties and Elections: Brazil's Democratic Experience Since 1985' in M. Kinzo and J. Dunkerley (eds.) Brazil Since 1985: Economy, Polity and Society. Institute of Latin American Studies: London, 42-62.

Kitschelt, H. and Wilkinson, S. (eds.) (2007) Patrons, Clients, and Policies, Patterns of Democratic Accountability and Political Competition. Cambridge University Press: Cambridge.

Knight, A. and Pansters, W. (eds.) (2005) Caciquismo in Twentieth-Century Mexico. Brookings Institute: Washington.

L'Abbate, S. (1989) 'As políticas de alimentação e nutrição no Brasil II. A partir dos anos setentas'. Revista de Nutrição da PUCCAMP 2(1): 7-54.

Landé, C. (1977) 'Group Politics and Dyadic Politics: Notes for a Theory' in S. W. Schmidt, L. Guasti, C. H. Landé and J. C. Scott (eds.) Friends, Followers, and Factions: A Reader in Political Clientelism. University of California Press: Berkeley, 506-510.

Leal, V. N. [1949] (1977) Coronelismo: The Municipality and Representative Government in Brazil. Cambridge University Press: Cambridge.

Leher, R. (2003) 'O governo Lula e os conflitos sociais no Brasil'. Observatório Social de America Latina IV(10): 81-129.

Lemarchand, R. and Legg, K. (1972) 'Political Clientelism and Development: A Preliminary Analysis'. Comparative Politics 4(2): 149-178.

MDSCF (2004) Análise comparativa dos programas de proteção social, 1995 a 2003. Ministério de Desenvolvimento Social e Combate á Fome: Brasília.

Nicolau, J. (2007) 'As bases municipais da votação de Lula em 2006'. Cadernos do Fórum Nacional 6:15-25.

Novelli, J. and Galvão, A. (2004) 'The Political Economy of Neoliberalism in Brazil in the 1990s'. International Journal of Political Economy 31(4): 3-52.

Portaria GM/MDS 246 (2005) Ministério de Desenvolvimento Social e Combate à Fome, May 20. [WWW document]. URL http://www.mds.gov.br/sobreoministerio/legislacao/ bolsafamilia/portarias/2005/Portaria\%20GM\%20MDS\%20246\%2020-5-05.pdf [accessed 13 November 2010].

Roett, R. (2003) 'Brazil's Protracted Transition to Democracy and the Market' in C. Wise and R. Roett (eds.) Post-Stabilization Politics in Latin America: Competition, Transition, Collapse. Brookings Institute Press: Washington, 199-221.

Salinas, R. (1988) Diconsa la modernización comercial y la regulación del abasto popular. Instituto Naciónal de Administración Pública: Mexico City.

Samuels, D. (2002) Ambition, Federalism, and Legislative Politics in Brazil. Cambridge University Press: Cambridge.

Samuels, D. (2008) 'The Gubernatorial Coattails Effect: Federalism and Congressional Elections in Brazil'. The Journal of Politics 62: 240-253.

Sedesol (2010) Secretaría de Desarollo Social. [WWW document]. URL http://www. sedesol.gob.mx [accessed 30 August 2010].

Soares, F. V., Soares, S., Medeiros, M. and Osório, R. (2006) Programas de transferência de renda no Brasil: impactos sobre a desigualdade, Anais do XXXIV Encontro Nacional de Economia. (Proceedings from the $34^{\text {th }}$ Brazilian Economics Meeting) 156, ANPEC - Associação Nacional dos Centros de Pósgraduação em Economia. Rio de Janeiro.

Taylor, L. (2004) Citizenship and Client-ship in Latin America. Lynne Reinner: Boulder. 
Copyright of Bulletin of Latin American Research is the property of Wiley-Blackwell and its content may not be copied or emailed to multiple sites or posted to a listserv without the copyright holder's express written permission. However, users may print, download, or email articles for individual use. 